\title{
Issues of Ecostrategies Implementation for Tourism Enterprises in Russia
}

\author{
Svetlana Bozhuk ${ }^{1, *}$ and Natalya Pletneva ${ }^{1}$ \\ ${ }^{1}$ Peter the Great St. Petersburg Polytechnic University, Politechnicheskaya st., 29, St. Petersburg, \\ 194064, Russia
}

\begin{abstract}
Ecological tourism in Russia has a high potential, however its extension creates an additional environmental burden. The decision of this contradiction is achieved by selection the marketing strategy of sustainable development which is adequate to the situation and cover all stakeholders involved in the producing, promotion and realization of tourist product.

Key words: tourism, analysis, ecological, sustainable development, environmental marketing
\end{abstract}

\section{Introduction}

In Russia, 2017 is declared as the Year of Ecology. This fact caught interest of many commercial entities to their own environmental practices. The business focused mainly on saving natural resources (non-waste technologies, energy efficiency), environment protection from harmful emissions (waste treatment, sewage disposal, air pollution control), wildlife preservation, and biological diversity. The principles of sustainable development can be realized in many ways in different business areas as each area has different options for minimizing the environmental footprint from the company's activities. Therefore, ecomarketing priorities may differ for each area, however, in any case, the consumers' concerns about environmental problems is a significant support to the company environmental activities.

A significant part of Russian consumers is interested in saving their money when paying utility bills, so a steady demand for water and energy saving household appliances can be observed.

According to many studies, the number of Russian consumers concerned about their health and beauty and, as a result, seeking to natural products consumption is constantly growing. This tendency has given rise to development of environmental marketing in such areas as organic cosmetics, food, clothing and footwear made of natural materials, environmentally friendly materials and household items.

The consumers eco-friendly attitude enables to expect interest growth in the Russian ecotourism development. In Russia, we can see many places with relatively primary nature. About 65 percent of the Russian Federation is almost unaffected by economic activity; ecosystems preserve biological productivity and biological diversity in full. To be sure,

\footnotetext{
* Corresponding author: bojuk.svetlana@yandex.ru
} 
Russia has a high tourist and recreational potential to develop all types of outdoor recreation tourism. Thus, the interest of tour professionals for development of ecotourism is very clear.

According to Government statistics, in 2016 the total number of tourist organizations amounted to about 87000 and the total value of commercial services in the tourism sphere (including hospitality and health-wellness sectors) amounted to more than 160 million rubles.

In 2016, foreign tourists made more than 24 million trips to Russia. Primarily, they were residents of Ukraine (8,5 million), Kazakhstan (3,5 million), Finland (1,32 million), China (1,29 million), Poland (1 million).

Ecotourism issues are widely discussed in the scientific literature and at the special industry conferences. Most scientists agree and recognize the distinctive features of ecotourism such as gentle environmental impact, provision of benefits to the local population, accompanying environmental awareness and education.

Various aspects of ecotourism development on the following studies.

The work by Andrades and Dimanche [1] was devoted to problems of destination image, infrastructure development, workforce training and education, quality management, and sustainable management.

The research by Sheresheva and Kopiski [2] sheds light on the key trends and challenges with respect to leveraging the cultural and economic potential of the Russian hospitality and tourism market.

The book «Tourism in Russia: a management handbook», edited by Dimanche and Andrades Caldito [3], describes challenges to sustainable tourism development in transition economies with special references to Russia. This book demonstrates the problems of tourism management in comparing the experience of Russia and other countries, which characterize the tourism resources. Such sectors as natural and health tourism are indicated.

Frolova et al. [4] were study the relationship between the development of tourism infrastructure and growth of the tourism industry, and the stereotypes, followed by tourists when choosing destinations for their journey.

Furthermore, numbers of researches is devoted to some aspects of the tourist business development: the existing tax incentives of the various actors in the tourism sphere, the specific questions of measuring and competitiveness forecasting in terms of competitive market [5], the issues of financial security of the Russian tour operators specializing in outbound tourism (tour operators specializing in outbound tourism) [6], and in some of them carried out the Classification of Tourism Potential by use of Cluster Analysis [7].

There are many types of ecotourism such as natural, rural (agrarian), adventure (extreme), scientific (cognitive) tourism, etc. Despite the discussions on specific differences, all authors recognize the long-term benefits of development of the ecological orientation of tourism in the Russian regions, because the intensification, for example, of active or rural tourism without ecological orientation can destroy natural objects and damage the environment. In this work, the authors adhere to a broad interpretation of ecotourism as the whole set of nature-oriented travels of different range and activity.

Currently, the share of nature-oriented ecotourism is about 1 percent of the overall structure of the Russian tourist market. According to the Federal Agency for Tourism of the Russian Federation, the creation of attractive routes to natural places untouched by human activities can provide an additional tourist flow of over $0.3 \mathrm{mln}$ people. The potential annual demand for rural tourism is estimated as $0.6 \mathrm{mln}$ people. At the 2 nd International Environmental Forum in Kaluga (September 13-14, 2016), A. Andrianov, the Executive Director of the National Agency for Sustainable Development, stated that ecotourism could become a real driver of the Russian economy. The perspective area of tourism provides rationale for study of formation features and estimation of marketing strategies efficiency 
oriented to principles of a sustainable development.

The purpose of this study is to analyze the main problems of formation and implementation of environmental marketing strategies for tour operators.

To achieve the purpose, the following tasks are set: to consider the capabilities of tour operators to adhere to the principles of sustainable development in Russia; to analyze the problems of ensuring the ecological attractiveness of a tourist product.

\section{Materials and Methods}

The study was based on the concept of Orsato [8] who proposed four variants of ecomarketing strategies:

- Environmental efficiency is defined by attention to the processes of reduction of the company overall costs through resource savings that allows to reduce the price for the consumer as well.

- Price leadership is also focused on the price competitive advantage, which allows obtaining a high price award from the environmental friendliness of the product itself.

- External leadership is a strategy based on differentiation of the company due to attention to the acology.

- Environmental branding differs by the product differentiation in the market as an ecological one.

To determine the ecological segments of the consumers, the classification of the Natural Marketing Institute (NMI) was used which involves grouping of consumers into five groups in accordance with their attitude to environmentally responsible businesses [9]:

- Environmental fighters (Lifestyles of Health and Sustainability - LOHAS). The main signs of behavior are activity, healthy lifestyle and desire to preserve the environment.

- Supporters of all natural. The main signs of behavior are taking care of their own health even at the expense of the natural environment.

- Undecided ones. The main sign of behavior is trendiness.

- Conventional ones. The main signs of behavior are pragmatism, desire to get the best value for money; they can support environmental initiatives when it is profitable.

- Apathetic ones. The main signs of behavior are lack of interest and awareness about social and environmental problems due to lack of time and money.

\subsection{Operational hypothesis}

Tour companies in Russia have access to the technologies allowing to save resources, protect environment from harmful emissions, however, these technologies are still too expensive for widespread use. Russian consumers are also not ready to provide significant support for the environmental activities of tourist companies, if this requires an increase in travel expenses. Thus, the eco-marketing priorities in this area are primarily related to saving resources allowing to reduce the companies' costs.

\subsection{Study methods}

Among scientific methods was chosen: systematic analysis of scientific literature, logical analysis, benchmarking of best practice in the field of sustainable development, author's study of consumer behavior.

The information for the study was obtained from 267 online application forms Google. The respondents were asked about their belonging to the environmental segment and preferences in the field of travel. Such form of the survey was chosen because of quick 
access to a young audience, which will determine the priorities of environmental consumption in the future.

The authors also conducted a content analysis of national parks' websites and natural attractions of World Heritage of UNESCO in Russia.

Also used secondary data of the survey conducted by VCIOM (Russian Public Opinion Research Center (VCIOM)); proceedings of the II International Ecological Forum in Kaluga in the section «Eco-tourism: status and prospects»; databases of the results of environmental certification "Ecological Union" and materials of analytical agency «TourStat».

\section{Results}

To determine the abilities of tour companies to adhere to the principles of sustainable development, it is necessary to clarify the composition of the goods offered on the market to consumers for exchange. The structure of the tour package (as a necessary minimum of services provided) can be considered as the basic components:

- vacation destination (tourist center),

- transport means to the vacation destination (main transport),

- accommodation and meals (accommodation services),

- movement within the vacation destination (transfer).

Thus, a full tour package of ecotourism will include protected natural areas or picturesque rural settlements as vacation destination, accommodation in ecological buildings, health food, transfer by ecological transport. Currently, just a few examples of such integrated approach to ecotourism can be found. In most cases ecotourism offers a tour to a place without civilization signs which puts in question its compliance with the requirements of sustainable development since active tourist activities can damage the environment. According to the Agency TurStat, in 2016 more than 9 million people made a cognitive journey through Russia's natural territories (national parks, sanctuaries and forest reserves). About $80 \%$ of visitors are accounted for the national parks of the Moscow region (Losiny Ostrov) and the Krasnodar Territory (Sochinsky) that indicates a significant impact on the local ecology.

However, the situation will change if the tour operator sets the task of suppliers and other stakeholders selection on the basis of conformity with the concept of sustainable development. Not only companies that provide accommodation (hotels, mini-hotels, campsites, etc.), catering services (cafe and restaurant), transportation; entertainment (including recreational facilities) and trade, but also producers of renewable energy sources, waste-processing organizations, local community and public organizations, employees, the media, etc. are considered as stakeholders.

For tour operators, the choice of the eco-marketing strategy is determined by the possibility of obtaining a competitive advantage of the company in the form of price reduction or differentiation through environmental practices (projects) or the ecological value of a tourist product.

When implementing a strategy aimed at environmental efficiency, the tour operators are trying to change the ecological footprint in those processes that provide cost reduction. An example of such strategies implementation is the construction of passive houses, use of paper or floor coverings from recyclable materials in hotels and restaurants, use of energy saving equipment and devices for rational water use.

Implementation of price leadership strategy can only be successful when working with segment of the high-income consumers considered as economically significant for the company. An example of a strategy of this kind is the Kapawi Lodge in the Amazonian rainforest offering luxury housing with minimal environmental impact. To generate 
electricity, they use solar panels, and the buildings are built in a traditional local style without nails. The cost of accommodation is $\$ 100$ per night. The tour operator works in close partnership with the local population; this provides only positive economic and social results from the activities. In Russia such examples are not yet known.

External leadership strategies are focused on environmental policy measures implemented in public interests. The examples of this strategy are the cases of investments in non-profit environmental projects: area clean-up operations, support of social movements for local flora and fauna protection, etc.

Application of environmental branding strategy is associated with the differentiation of offers due to ecological value of tourism products. Primarily, the item of ecological value is the tourist center (nature reserve), and less often this is the place of residence (eco-hotels) and organic food (rural tourism).

If the traveler attraction has a natural uniqueness, its branding facilitates the formation of awareness among the general audience and makes it popular and even fashionable to visit. In order to inform tourists, information portals, mobile applications and other media products are created to provide comprehensive information in different languages and make a set of impressions, well-known all over the world.

The research of Russian tourist centers included in the UNESCO World Heritage List has shown weak efforts in the field of branding. The main source of information about tourist centers for consumers is Internet resources. Correct presentation of information about the uniqueness of a natural site not only creates awareness, but also forms expectations, fixes positive emotions, creating a sustainable image of the branded object. For example, Lake Baikal is a natural UNESCO World Heritage site, which supports several top-rated information portals (though not always in several languages) for the tourism development. From 11 Russian natural sites included in the UNESCO World Heritage List, only one does not have its own information portal (Western Caucasus), although the information is widely represented on the sites of various tourist guides. Three natural sites have web-sites with the official reserve name that is not known to all tourists. By the short UNESCO name, you can find information only on the web-sites of tourist guides. Thus, it is difficult to talk about the development of environmental branding in the tourism industry, even if the Russian UNESCO natural heritage assets are not a sample of such a strategy.

Some representatives of the tourism industry are actively positioning themselves as ecohotels, but in fact, they can not confirm their statute with certificates or with significant environmental responsibility. The addition of "eco" rather describes the location not spoiled by civilization, than the building or lean practice.

Best practices benchmarking has shown that "green" technologies can ensure the development of ecotourism in Russia, however, they require significant and sustained investment in the tourist centers.

The situation with environmentally friendly food is the most transparent. In 2015, Russia adopted a national standard for organic and agricultural products that allows all interested companies to confirm their status. For example, in the North-West region two organic farms that are certified according to organic standard of ICEA (the Italian Institute of Ethical and Organic Certification - IACBs Equivalent EU Standard), harmonized with the European one, are under development. According to NP Ecological Union these are Alohovschina farm in Lodeinopolsky region and Zhivoeye Pole in Kirov region. In total, 14 manufacturers are certified in Russia.

Today in Russia there are a lot of examples of successful cooperation in the field of agricultural production, catering and shopping businesses. Some retail store chains are formed around itself a pool of proven farmers. For example, a retail chain $A B C$ of Taste (Azbuka Vkusa) arranged a cooperative farm with dozens of private traders and packages 
milk, meat, cereals and vegetables under the brand "Nasha Marka" (Our Brand). Turnover of organic products in the ABC of Taste is kept confidential, it is known that in 2014 it grew by $21 \%$ compared with the previous year, and the company intends to expand its production. However, there are no examples of attracting such companies to the Russian tourism industry. The Russian tourism industry is still weakly interested in differentiating its offer as ecologically oriented, but gastronomic tours in Europe are well known.

There are examples of ecological construction also. "Green" construction should solve the tasks of reducing water consumption, energy consumption and heat losses, sorting and recycling of garbage. In Europe, considerable experience has been gained in the construction and successful reconstruction of buildings into passive houses, for example, in Peltosaari (Finland) after reconstruction of multistory apartment house energy consumption has been reduced in half [10].

The ambitious project of environmentally friendly city is implemented in the Chinese mountainous region of Guangxi in an area of 175 hectares. It is assumed that in the new city 30 thousand people will be settled in houses designed as vertical gardens. The buildings are equipped with air filtration and water purification systems. Electricity is provided by solar panels, travel around the city - by electric transport, and connection with other settlements - by high-speed rail [11].

In Moscow microdistrict Nikulino 2 heat pumps for hot water and the outer fencing structures with increased thermal protection were first used in Russia [12]. There are other examples of energy efficient low-height building in suburbs of major Russian cities. For example, a group of companies EcoDolie in Ekaterinburg became the first in Russia that received the World Award FIABCI Prix d'Excellence for the environmental compatibility in low-height building [13].

The activity of builders is constrained by an increase in the cost of a building built according to "green" technologies, at least $10-15 \%$ higher than conventional construction. According to experts of YIT Homes opinion, in Russia each percent of energy saving used practically increases the cost of construction by $1 \%$ too. So, "green" technologies which save $30 \%$ of electricity automatically increase the cost of construction by one third [14]. However, in the long-term cumulative costs for construction and operation of "green" buildings turn lower, and additional costs are compensated.

Now, in Russia, 10 facilities in Moscow and the Moscow region, 7 facilities in St. Petersburg, 2 facilities in Tver and the Tver region, 1 facility in Dzerzhinsk and 1 facility in Ulyanovskin, are certified in accordance with the international environmental standard for LEED buildings (The Leadership in Energy \& Environmental Design). Another 50 facilities are under certification now. There are no facilities related to the tourism industry among them.

36 facilities in Moscow and the Moscow region, 8 facilities in St. Petersburg, 7 facilities in Sochi, 12 facilities in other cities of Russia are certified by the BREEAM method (Building Research Establishment's Environmental Assessment Method). And only 2 of them are hotels (located in Sochi).

In 2012, GOST R 54964-2012 "Conformity assessment. Ecological requirements for estate properties" was put into force in Russia. And in 2014, the standard of energy efficiency named the "GREEN ZOOM" was also developed. Evaluation of real property is carried out in view of the object location and environmental sustainability of land plot, transport support, water and energy efficiency, reducing harmful emissions into the atmosphere, the selection of construction materials and waste management, indoor ecology and innovation. Today 21 facilities are certified, and 7 facilities are in the process of GREEN ZOOM certification. Among them there are 8 residential complexes and a whole microdistrict (in Yekaterinburg), the objects of the tourism industry are also not represented. 
The prospects of using ecological transport are becoming real. The leading car brands (Mercedes, Porsche, Aston Martin, BMW, Volvo Chevrolet, Volkswagen, Citroen, Fiat, Ford, Hyundai) presented advanced models of electric vehicles, which will be put into production. The model range offers both miniature two-seater models (for example, electric car Microlino EV costs $\$ 1,000$, accelerates up to $100 \mathrm{~km} / \mathrm{h}$ and is able to cover the distance of $100 \mathrm{~km}$ before the battery recharging), and prestigious versions (Tesla electric cars cost more than $\$ 35,000$ and are able to cover the distance of more than $400 \mathrm{~km}$ before recharging).

The PHEV (plug-in hybrid electric vehicle) is an advance technology also. The PHEV advantages are that they can move on conventional fuel, charging their electric batteries while moving. Thus, the problem of limiting the travel distance by a battery resource is solved, the owner has the ability to charge the battery from the mains in a convenient place.

The main problems that prevent the spread of electric vehicles in Russia are their high cost and a short range of travel. In the Russian market AvtoVAZ represents one model BA3-1817 ELLADA (cost of $1.2 \mathrm{mln}$ rubles) which is operated in the Krasnodar Territory. Mikhail Prokhorov at the Geneva Motor Show in 2016 introduced the concept Yo-Move electric vehicle with cost of $\$ 10,000$ but the model did not enter in mass production. The task of sustainable transport creation is solved by KAMAZ jointly with Skolkovo within the framework of the "Electrochemistry 2015". However, electric buses have not yet become a universal eco-transport. It is also too early to talk about ecological trunk transport.

\section{Discussion}

In general, we can state that today there are technological opportunities to provide an ecological tour package in Russia. However, examples of the application of "green" technologies are differentiated and do not represent systematic practice.

The activity of introducing environmental innovations is determined by the state of environmental interest of target consumers.

The authors conducted a series of studies of potential consumers to clarify the behavior patterns and portraits of typical representatives of segments exhibiting different environmental responsibilities.

In the course of the study in the spring of 2017, in-depth interviews and an Internet survey were conducted to identify the motives for choosing a holiday package, the presence of interest and the current consumer perceptions of ecotourism for each ecological segment.

The results have demonstrated that the segment of "apathetic consumers" may show an interest in ecotourism out of curiosity, they are willing to discover something new without blowing their budget. At the same time, there is no the value of the environmental proposal for them, they are passive when choosing a tour package and have no idea about ecotourism. In everyday life, they are not ready to experience any inconvenience for solving environmental problems.

The represents of "conventional" segment are ready to travel to ecologically clean territories provided an acceptable price for the tour package. They have an idea of ecotourism from this point of view, but without going into the nuances of the natural and rural tourism. They pragmatically connect outdoor recreation with health benefits and cheapness, and believe that such places can be easily found in Russia. Little attention is paid to other aspects of the environmental situation. They are environmentally responsible only within the framework of their interests.

"Undecided ones" have the most general ideas about the relationship between human activities and environmental problems, pay attention to picturesque places for a photo session, always in search of new impressions, but the value of an environmental proposal 
for them is determined by fashion trends or friends' recommendations. They have no idea about the peculiarities of ecological tourism. They believe that hikes and other types of outdoor activities are suitable for this category. They are not ready to make any additional efforts to protect the environment, to give up comfort, but try to follow certain elementary rules of conduct ("do not litter", "do not make a fire in the wrong place", etc.).

"Supporters of all natural" make high demands for the place of accommodation, follow the healthy atmosphere and food, have a vacation experience in eco-hotels, but pay little attention to the consequences of human activities for the environment.

"Environmental fighters" are not only well aware of the environmental friendliness of the chosen vacation destinations, but also ready to follow in everyday life all the recommendations for solving environmental issues and to incur additional costs in order to minimize the harm to the environment not only during travel. However, the interests of travel of this segment are not limited by tours to nature reserves. For this segment, environmental conditions of accommodation are important, without reference to the tourist center. Most of them believe that ecologically clean territories can be found only abroad.

It is obvious that detailed definition of the portrait of ecological segments according to the NMI classification in tourism did not bring any surprises concerning environmental consumption, but allowed to reveal a weak awareness about certain components of ecologically oriented recreation and ecotourism opportunities in Russia. The consumers perception distortion regarding the vacation destination ecology is also noticeable.

\section{Conclusions}

The results of the quantitative research allow us to identify the attitude of consumers towards the environmental responsibility of the companies in the field of tourism. The contingent of respondents is mainly young people under 25 years old, and a third part of consumers are persons of 26-45 years old. Two-thirds of respondents view themselves as a middle class who can afford to buy farm products, travel at least once a year, planning a vacation with sufficient care.

Among the significant factors affecting the choice of the tour, respondents indicated low cost, visitor reviews and ecology of the vacation destination. At the same time to maintain the place ecology, most respondents do not do anything. Only $18 \%$ of respondents had experience of ecotourism, and less than half of respondents are interested in places not affected by civilization.

This confirms once again that the consumers views about the ecology of the vacation destination are highly distorted. Representation of the environmental responsibility of the tourism industry does not affect the consumer choice.

Unfortunately, a quantitative online survey does not allow us to accurately estimate the size of environmental segments, since the sample is not random, and it is difficult to distribute the obtained results to the entire population of consumers. According to researchers' opinion, about $20 \%$ of the sample can be classified as "apathetic", $19 \%$ "undecided" and "conventional", which, in general, within the margin of error, corresponds to the research conducted by other authors. "Supporters of all natural" are represented by $35 \%$ of the respondents. "Environmental fighters" are very few in number.

It is clear that neither consumers nor the state supports the ecological orientation of the tourism industry representatives. Russian tourism industry is interested weakly to differentiate its offer as environmentally valuable yet, since it requires a significant and sustained investment. The use of "green" technologies aimed to resource economy is gradually expanding in Russia, however, it is not a systematic practice in the tourist centers. To be actually developed, the ecotourism sector requires a national program which will enable not only to expand the range of the offered tourism products, but also to take 
measures to preserve he heritage for future generations

The study was devoted to the problems of sustainable development of the tourism industry.

The background of the Ecotourism conception formulation was the study of the positive experience of environmental in the building sphere, transport environmental, meals environmental.

A study of the experiences of different companies has allowed us to identify the factors contributing to and hindering the development of ecotourism in Russia.

The main barrier for total implementation of the Ecotourism conception is the lack of demand from consumers for a full touristic package, which including not only the protected natural areas or picturesque rural settlements as vacation destination, but also accommodation in ecological buildings, health food, transfer by ecological transport.

That's why, in most cases ecotourism offers a tour to a place without civilization signs which puts in question its compliance with the requirements of sustainable development since active tourist activities can damage the environment.

\section{References}

1. L. Andrades, F, Dimanche, Destination competitiveness and tourism development in Russia: Issues and challenges. Tourism management, 62, 360-376 (2017)

2. M. Sheresheva; J. Kopiski, The main trends, challenges and success factors in the Russian hospitality and tourism market. Worldwide hospitality and tourism themes, 8(3), 260-272 (2016)

3. F. Dimanche, L. Andrades Caldito, Tourism in Russia: a management handbook, United Kingdom: Emerald, 448 p. (2015)

4. E.V. Frolova, O.V Rogach, E.E. Kabanova, N.V. Medvedeva, I.Y. Shimanskaya, Tendencies and prospects of tourism industry in Russia: Sociological analysis of stereotypes among population during tourism trips. European Research Studies Journal, 20(2), 308-320 (2017).

5. N.N. Koroteeva, E.L Hasanov, V.A. Mushrub, V.V Bakharev, R.A Shichiyakh, The conditions of economic efficiency and competitiveness of tourism enterprises. International Journal of Economics and Financial, 6(8), 71-77 (2016)

6. G.R Bakieva, L.F. Muftieva, Management analysis as means of improving the business processes at the tourist enterprise: A case study. International Journal for Quality Research, 10(4), 761-768 (2016)

7. P. Chalupa, M. Prokop and J. Rux, Use of Cluster Analysis for Classification of Tourism Potential. Littera Scripta, 6(2), 59-68 (2016)

8. R. Orsato, Competitive Environmental strategies: When does it pay to be green? California Management review, 48(2), 131 (2006)

9. J. Grant, Green marketing. Strategic Direction, 24(6), 25-27 (2008)

10. V. Bozhuk, Sustainable development in architecture and urban planning, (2017)

11. U. Bezborodova, China to build the first city-forest, (2017)

12. Official site of the group of companies Pi-ANA, PIANA HR GROUP [online], Available at: http://www.pianahrgroup.com/ (2017)

13. Official site of the group of companies Ecodolie, Ecodolie [online], Available at: http://www.ecodolie.ru/ (2017) 
14. D. Truman, When in Russia will start to build an ecological house?, Green house [online], Available at: http://green-dom.info/3\%D0\%B0\%D0\%BB $\%$ D1\%8C $\%$ D1 $\% 82 \% \mathrm{D} 0 \% \mathrm{~B} 5 \% \mathrm{D} 1 \% 80 \% \mathrm{D} 0 \% \mathrm{BD} \% \mathrm{D} 0 \% \mathrm{~B} 0 \% \mathrm{D} 1$ $\% 82 \% \mathrm{D} 0 \% \mathrm{~B} 8 \% \mathrm{D} 0 \% \mathrm{~B} 2 \% \mathrm{D} 0 \% \mathrm{BD} \% \mathrm{D} 0 \% \mathrm{~B} 0 \% \mathrm{D} 1 \% 8 \mathrm{~F}-$

$\% \mathrm{D} 1 \% 8 \mathrm{D} \% \mathrm{D} 0 \% \mathrm{BD} \% \mathrm{D} 0 \% \mathrm{~B} 5 \% \mathrm{D} 1 \% 80 \% \mathrm{D} 0 \% \mathrm{~B} 3 \% \mathrm{D} 0 \% \mathrm{~B} 5 \% \mathrm{D} 1 \% 82 \% \mathrm{D} 0 \% \mathrm{~B} 8 \% \mathrm{D} 0$ \%BA\%D0\%B0/\%D0\%BA\%D0\%BE\%D0\%B3\%D0\%B4\%D0\%B0-\%D0\%B2-

$\% \mathrm{D} 1 \% 80 \% \mathrm{D} 0 \% \mathrm{BE} \% \mathrm{D} 1 \% 81 \% \mathrm{D} 1 \% 81 \% \mathrm{D} 0 \% \mathrm{~B} 8 \% \mathrm{D} 0 \% \mathrm{~B} 8-$

$\% \mathrm{D} 0 \% \mathrm{BD} \% \mathrm{D} 0 \% \mathrm{~B} 0 \% \mathrm{D} 1 \% 87 \% \mathrm{D} 0 \% \mathrm{BD} \% \mathrm{D} 1 \% 83 \% \mathrm{D} 1 \% 82-$

\%D1\%81\%D1\%82\%D1\%80\%D0\%BE\%D0\%B8\%D1\%82\%D1\%8C-

\%D1\%8D\%D0\%BA\%D0\%BE\%D0\%BB\%D0\%BE\%D0\%B3\%D0\%B $8 /$ (2013) 